carrying British species occupy six, and those carrying Continental European species occupy fifteen large cabinets. Most of the plants in this herbarium were collected by White himself on his walks and travels at home and abroad, but numerous additions have from time to time been made by exchange and purchase. The specimens are beautifully mounted, well labelled, carefully catalogued and useful notes and relevant cuttings are frequently attached to the sheets. White was the author of "The Flora of Bristol", published in 1912, which is rightly considered a model of what a county flora should be. His herbarium is, however, of far more than merely local importance. The accuracy and critical nature of his determinations make it of real scientific value and wide general interest. By coming into possession of this herbarium the hortus siccus of the University of Bristol has become one of the four best-equipped university herbaria in England.

\section{Verulamium, 1932}

Excavations at St. Albans in 1932, of which Dr. and Mrs. R. E. Mortimer Wheeler gave an account at the Society of Antiquaries on February 23, have again added to the impressiveness of the prehistoric site and enhanced its importance as a source of knowledge of conditions in Britain immediately before the Roman invasion. The chance discovery in 1932 of a hoard of silver coins a mile north of the Abbey in the dyke running across country from the north of St. Albans in the direction of the village of Sandridge, not only proved the existence of the dyke before the second century A.D., but also led to the determination of the true character of this remarkable work, which is $100 \mathrm{ft}$. broad, 30-40 ft. deep and some five miles long, as a British defensive work extending from the pre-Roman eity at the south-west of St. Albans to prehistoric works, of which the remains are still to be seen at Wheathampstead. Excavations here in the past summer have shown this to be a prehistoric 'city' about a hundred acres in extent, the most remarkable of its kind in the period yet found in Britain. It would appear that this great work was constructed by the Belgic invaders of Britain, who established their headquarters at St. Albans towards the end of the first century B.c. In his account of the past year's exploration of the Roman city, Dr. Wheeler drew a gloomy picture of the social and economic depression, alleviated only by a brief and illusory recovery, which invaded Verulamium as Roman power declined, after a brilliant and perhaps too optimistic efflorescence of prosperity. In the juxtaposition of pre-Roman and Roman on an extensive scale and in the evidence of the varied fortunes of a prolonged Roman occupation, St. Albans, under continued exploration, promises to become one of the most instructive and impressive archæological sites on the fringe of the Roman Empire in the western world.

\section{Federal Council for Chemistry}

IN its report for 1932, the Federal Council for Chemistry refers with regret to the necessary postponement of the ninth International Congress of
Pure and Applied Chemistry and the eleventh conference of the International Union of Chemistry, which were to have been held in Madrid in 1932 . The next meeting of the Union will take place in the spring of 1934 in Madrid, and not in Switzerland, as previously arranged. During the year, the Verein Oesterreichischer Chemiker and the Svenska National Kommitten för Kemie were elected members of the International Union. The report refers to a conference on chemical documentation, held in Paris in October 1932, and indicates that the Federal Council and the Division of Chemistry and Chemical Technology of the U.S. National Research Council are in complete agreement with regard to certain criticisms of the activities of the International Committee dealing with the reform of biochemical nomenclature. The efforts of the British Standards Institution to extend the use of the words "British Standard" to include "chemical substances used in manufactures, photography, or philosophic research and anti-corrosives" were supported by the Federal Couneil. The Board of Trade agreed to the Institution proceeding with an application to register provided that it was in a position to submit support from the appropriate trade association or similar body. A significant passage in the report is as follows: "In October, a Committee consisting of Dr. E. F. Armstrong, Mr. E. R. Bolton, Dr. L. H. Lampitt, Prof. G. T. Morgan, Mr. Emile Mond, Prof. J. C. Philip, Sir William Pope, Mr. J. Davidson Pratt, and Mr. D. Rintoul was appointed 'To consider how the resources of the various bodies concerned with the professional and scientific welfare of chemists can be most economically and efficiently utilised'. This Committee has met on several occasions, and will present, early in 1933, a report on its findings for consideration by the Federal Council." We shall look forward with interest and expectation to the outcome of the deliberations of so representative a committee, which is dealing with a matter of national as well as professional importance.

\section{Photographic Analysis of Explosion Flames}

At the Friday evening discourse at the Royal Institution on February 24, Prof. W. A. Bone discussed "The Photographic Analysis of Explosion Flames". Nowadays the photographic analysis of explosion flames has become an indispensable part of the scientific study of explosions. Prof. Bone described first, with experimental illustrations, how the earlier work of Mallard and Le Chatelier and of Berthelot and Vieille in France, as well as that of H. B. Dixon and his collaborators in Great Britain, during the period 1883-1903, revealed, not only the successive stages in gaseous explosions, but also much about the nature of the final phase of 'detonation' (l'onde explosive) with its intensive chemical action, high constant velocities (one or two metres per second) and shattering effects. Prof. Bone then dealt principally with recent developments in the designing of high-speed cameras by Mr. R. P. Fraser at the Imperial College, South Kensington, where it has now become possible not only to photograph, 
but also to analyse with precision, periodic movements in explosion flames occurring with frequencies up to a million a second. A number of the resulting photographs were exhibited showing the influence of compression waves in accelerating explosion flames and setting up detonation therein and, more particularly, the new phenomenon of 'spin' in detonation, which is due to a highly luminous comet-like 'head' of detonation spiralling through the medium with a frequency of several tens of thousands a second, and appears to be a concentrated locus of positively charged particles. These developments are not merely important but have also opened up a new field in the investigation of the propagation of chemical change through gaseous media under the most intensive conditions of temperature and pressure.

\section{Recent Acquisitions at the British Museum (Natural History)}

The Rev. A. H. Cooke has given the whole of his collection of shells of land-snails of the genus Clausilia and of the dog whelk (Thais lapillus); the former is very rich in series from central Europe and the Balkans, and the latter includes specimens from practically the whole distributional area, and illustrates very completely the remarkable variation of this species. Recent accessions to the Department of Entomology include the final instalment, consisting of several hundred Hymenoptera, of the very large amount of material collected by the Percy Sladen Trust Expedition to the Seychelles and other islands of the western Indian Ocean. This expedition, which was led by Prof. (then Mr.) Stanley Gardiner, in 1905 and 1908-9, resulted in the gift of many thousands of specimens to the Museum. The final instalment consists almost entirely of small or minute wasps, many of them obviously new, which it has so far proved impossible to work out owing to the lack of specialists in these groups. The Department has also received a set of the Hymenoptera collected on the island of Rodriguez by the late H. J. Snell and by Mr. H. P. Thomasset. From Mount Kina Balu in North Borneo a series of a new species of Blepharocera has been sent by Mr. H. M. Pendlebury. Flies of this genus have hitherto been found only in the north temperate regions, and their discovery in Borneo is therefore both surprising and of importance in zoogeography. The larvæ of these insects live only in waterfalls and rapids, attaching themselves to rocks and stones by means of ventral suckers; and it has been considered therefore that they would be able to spread only along land routes. The four, widely separated, compound eyes in this species give the head a most remarkable appearance. The American Museum of Natural History has presented to the Department of Geology a model of an extinct straight-tusked elephant.

Game Animals in the British Museum (Natural History)

Tre Trustees of the British Museum announce the closing of the exhibition of the game animals of the British Empire in the New Whale Gallery at the Natural History Museum on March 19. As, owing to the financial stringency, it was impracticable to begin last year the removal of the exhibited specimens of whales to their new quarters, the Trustees decided to use the space available for the temporary exhibition of the game animals, grouped by the three great faunal regions in which they occur and arranged without glazed cases. Unhappily the skins are attractive to moths; it would therefore be risky to leave the specimens exposed when the moths begin to fly in spite of the daily dusting which these skins receive, and they will be returned to their cases before the end of the month. Capt. Guy Dollman, who was responsible for the arrangement of the exhibition, will talk in the New Whale Gallery about the animals in the three great faunal regions at 11.30 on March 4, Indo-Malaya; March 11, Africa; March 18, Canada and Newfoundland. Visitors will be admitted free.

\section{Ross Institute for Tropical Diseases}

Aт a recent meeting of the Industrial Advisory Committee of the Ross Institute, Putney Heath, London, S.W., reports were received of the over-seas activities of the Institute. Seven research centres in Assam and northern Bengal have been opened, and anti-malarial work and the testing of new drugs for the treatment of malaria have been pursued there and in Rhodesia and East and South Africa. In the Assam tea gardens, anti-malarial work has resulted in much improved health, for in 1930 among a population of 13,248 the admissions to hospital were 23,226 but in 1932 with a slightly larger population the admissions were reduced to 15,141. A standard oil mixture for killing mosquito larvæ has been devised in conjunction with the Burma-Shell group. The health among lead miners in Yugoslavia was investigated and a health scheme was formulated and is now in operation. At the conclusion of the proceedings, Mr. Still and Sir Malcolm Watson addressed the meeting on the subject of yellow fever. Now that travel by aeroplane is so rapid, the grave danger that infection may be carried from the yellow fever zone in West Africa to East Africa and Asia, which would be followed with disastrous consequences, was emphasised.

\section{Norwegian Antarctic Expedition}

Capt. H. Risser-Larsen, the leader of the forthcoming Norwegian expedition to the antarctic, has outlined his plans in the Polar Record for January. With two companions and eighty dogs, he hopes to be landed from a whaler at Enderby Land early this year. A hut will be built as a base for the winter months but various sledge journeys will be made in April and May. In the spring the three men will start sledging westward over the sea-ice along the coast of the Weddell Sea to Snow Hill or Hope Bay in Graham Land, where supplies were to be landed by a whaler this (southern) summer. The expedition is to be picked up early in 1934. A short wave radio equipment will be carried which will make it possible for arrangements with the whaler to be altered. Capt. Riiser-Larsen believes, from his view of the 